\title{
Article \\ Choline-Sigma-1R as an Additional Mechanism for Potentiation of Orexin by Cocaine
}

\author{
Jeffrey L. Barr ${ }^{1,+}{ }^{\text {, Pingwei Zhao }}{ }^{1}$, G. Cristina Brailoiu ${ }^{2}$ and Eugen Brailoiu ${ }^{1, *}$ \\ 1 Center for Substance Abuse Research, Lewis Katz School of Medicine at Temple University, \\ Philadelphia, PA 19140, USA; Jeffrey.Barr@SanfordHealth.org (J.L.B.); zhaopw@temple.edu (P.Z.) \\ 2 Department of Pharmaceutical Sciences, Jefferson College of Pharmacy, Thomas Jefferson University, \\ Philadelphia, PA 19107, USA; Gabriela.Brailoiu@jefferson.edu \\ * Correspondence: eugen.brailoiu@temple.edu \\ + Current address: Cancer and Immunotherapies Group, Sanford Research, Sioux Falls, SD 57104, USA.
}

check for updates

Citation: Barr, J.L.; Zhao, P.; Brailoiu, G.C.; Brailoiu, E. Choline-Sigma-1R as an Additional Mechanism for Potentiation of Orexin by Cocaine. Int. J. Mol. Sci. 2021, 22, 5160 https://doi.org/10.3390/ ijms22105160

Academic Editor: Carmen Abate

Received: 5 April 2021

Accepted: 11 May 2021

Published: 13 May 2021

Publisher's Note: MDPI stays neutral with regard to jurisdictional claims in published maps and institutional affiliations.

Copyright: (c) 2021 by the authors. Licensee MDPI, Basel, Switzerland This article is an open access article distributed under the terms and conditions of the Creative Commons Attribution (CC BY) license (https:// creativecommons.org/licenses/by/ $4.0 /)$

\begin{abstract}
Orexin A, an endogenous peptide involved in several functions including reward, acts via activation of orexin receptors $\mathrm{OX}_{1}$ and $\mathrm{OX}_{2}, \mathrm{Gq}$-coupled GPCRs. We examined the effect of a selective $\mathrm{OX}_{1}$ agonist, OXA (17-33) on cytosolic calcium concentration, $\left[\mathrm{Ca}^{2+}\right]_{\mathrm{i}}$, in neurons of nucleus accumbens, an important area in the reward circuit. OXA (17-33) increased $\left[\mathrm{Ca}^{2+}\right]_{\mathrm{i}}$ in a dose-dependent manner; the effect was prevented by SB-334867, a selective $\mathrm{OX}_{1}$ receptors antagonist. In $\mathrm{Ca}^{2+}$-free saline, the OXA (17-33)-induced increase in $\left[\mathrm{Ca}^{2+}\right]_{i}$ was not affected by pretreatment with bafilomycin A1, an endo-lysosomal calcium disrupter, but was blocked by 2-APB and xestospongin $\mathrm{C}$, antagonists of inositol-1,4,5-trisphosphate $\left(\mathrm{IP}_{3}\right)$ receptors. Pretreatment with VU0155056, PLD inhibitor, or BD-1047 and NE-100, Sigma-1R antagonists, reduced the $\left[\mathrm{Ca}^{2+}\right]_{\mathrm{i}}$ response elicited by OXA (17-33). Cocaine potentiated the increase in $\left[\mathrm{Ca}^{2+}\right]_{i}$ by OXA (17-33); the potentiation was abolished by Sigma-1R antagonists. Our results support an additional signaling mechanism for orexin $\mathrm{A}-\mathrm{OX}_{1}$ via choline-Sigma-1R and a critical role for Sigma-1R in the cocaine-orexin A interaction in nucleus accumbens neurons.
\end{abstract}

Keywords: choline; orexin $\mathrm{A}$; $\mathrm{OX}_{1}$ receptor; phospholipase D; PLD; reward

\section{Introduction}

Orexin A and B (also known as hypocretin-1 and -2) are endogenous neuropeptides synthesized in hypothalamic neurons that control appetite, sleep/wakefulness, hormone release, stress, and drug-seeking behavior [1-3]. Hypothalamic neurons expressing orexins project to several brain areas such as ventral tegmental area, nucleus accumbens, dorsal raphe nucleus, and locus coeruleus $[2,4]$.

Orexins act via $\mathrm{OX}_{1}$ and $\mathrm{OX}_{2}$ receptors, Gq-coupled GPCRs that may signal also via Gs or Gi proteins $[5,6]$. $\mathrm{OX}_{1}$ receptors have a preferential role in addiction, reward, and motivation, while $\mathrm{OX}_{2}$ receptors are involved in arousal [3,7]. $\mathrm{OX}_{1}$ receptor activation leads to an increase in cytosolic $\mathrm{Ca}^{2+}$ concentration, $\left[\mathrm{Ca}^{2+}\right]_{i}$, subsequent to activation of phospholipase C (PLC) and generation of inositol-1,4,5-trisphosphate $\left(\mathrm{IP}_{3}\right)[6,8]$. In addition to the PLC coupling, activation of $\mathrm{OX}_{1}$ receptor leads to phospholipase $\mathrm{D}$ (PLD) activation $[9,10]$. PLD-mediated hydrolysis of phosphatidylcholine produces choline and phosphatidic acid [11]. Choline activates Sigma-1R [12], a chaperone protein residing at the endoplasmic reticulum that potentiates $\mathrm{IP}_{3}$-induced $\mathrm{Ca}^{2+}$ release [13].

$\mathrm{OX}_{1}$ receptors were identified in brain nuclei from the reward circuit, including nucleus accumbens $[14,15]$, and $\mathrm{OX}_{1}$-selective antagonists have been evaluated as potential therapeutic agents for addiction treatment [16-18]. Previous studies indicate that orexins via $\mathrm{OX}_{1}$ receptor activation are involved in the response to cocaine and play multiple roles in cocaine addiction-related behaviors [7,19-21]. Orexin-OX $\mathrm{X}_{1}$ signaling is required for stimulant locomotor sensitization and cocaine seeking when it is driven by highly 
motivated states [3]. $\mathrm{OX}_{1}$ receptors in the nucleus accumbens mediate chronic cocaineinduced locomotor sensitization [22]. Other studies indicate that SB-334867, a selective $\mathrm{OX}_{1}$ receptor antagonist, prevents cocaine seeking and is a potential treatment target for cocaine relapse prevention [23].

Cocaine acts primarily by blocking the dopamine transporter, thus increasing dopamine transmission in the nucleus accumbens [24], an important area in the reward circuit [25]. In addition, cocaine binds to and activates Sigma-1R [26]. Since nucleus accumbens neurons express Sigma-1R [27-29] and $\mathrm{OX}_{1}$ receptors [14,15] and behavioral studies support the cocaine-orexin interaction at this level [3,22], in this work, we examined the underlying mechanisms and role of Sigma-1R in the cocaine-orexin interaction in nucleus accumbens neurons.

\section{Results}

2.1. OXA (17-33) Increases Cytosolic $\mathrm{Ca}^{2+},\left[\mathrm{Ca}^{2+}\right]_{i}$, in Nucleus Accumbens Neurons via OX Receptor Activation

OXA (17-33) (0.1-100 nM), i.e., truncated orexin A, a selective OX1 agonist [1,30], increased $\left[\mathrm{Ca}^{2+}\right]_{\mathrm{i}}$ in nucleus accumbens neurons in a dose-dependent manner (Figure 1). OXA (17-33) $(10 \mathrm{nM})$ increased the fluorescence F340/380 ratio of Fura-2AM-loaded nucleus accumbens neurons; the effect was prevented by pretreatment with SB-334867 $(1 \mu \mathrm{M})$, a selective $\mathrm{OX}_{1}$ antagonist [31] (Figure 1A). OXA (17-33) $(10 \mathrm{nM})$ produced a transient increase in $\left[\mathrm{Ca}^{2+}\right]_{\mathrm{i}}$ that was abolished by SB-334867 (Figure 1B). Comparison of the amplitude of the increase in $\left[\mathrm{Ca}^{2+}\right]_{\mathrm{i}}$ produced by different concentrations of OXA (17-33) $(0.1,1,10,100 \mathrm{nM})$ is illustrated in Figure 1C ( $n=6$ neurons/each concentration). Of note, 20-30 neurons were tested for each condition, and an increase in $\left[\mathrm{Ca}^{2+}\right]_{i}$ was identified in about $25 \%$ of neurons tested; the amplitude of $\left[\mathrm{Ca}^{2+}\right]_{i}$ from the response of six neurons was used for analysis.

A
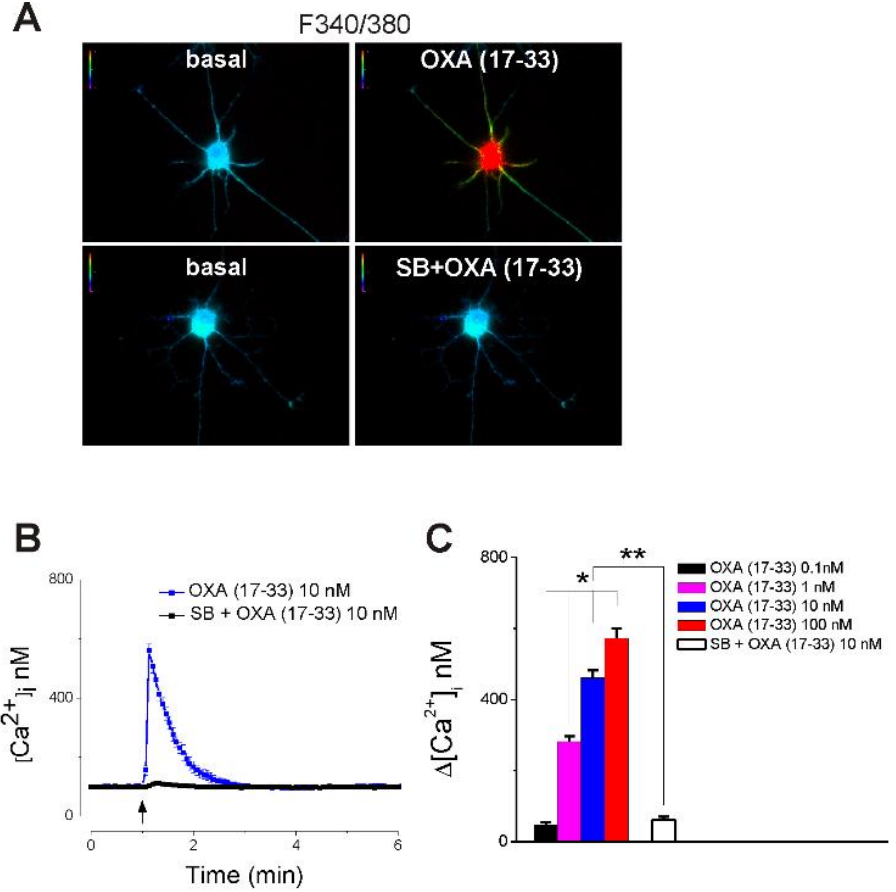

Figure 1. OXA (17-33) increases cytosolic $\mathrm{Ca}^{2+}$ concentration, $\left[\mathrm{Ca}^{2+}\right]_{i}$, in nucleus accumbens neurons via $\mathrm{OX}_{1}$ receptor activation. (A) Representative examples of fluorescence F340/380 ratio of Fura-2AMloaded nucleus accumbens neurons in basal conditions (left) and after treatment with OXA (17-33) $(10 \mathrm{nM})$, a selective $\mathrm{OX}_{1}$ agonist, alone (top right) or in the presence of $\mathrm{OX}_{1}$ antagonist, SB-334867 $(1 \mu \mathrm{M})$ (bottom right). (B) OXA (17-33) $(10 \mathrm{nM})$ produced a transient increase in $\left[\mathrm{Ca}^{2+}\right]_{i}$; the effect was abolished by SB-334867. (C) Comparison of the amplitude of $\left[\mathrm{Ca}^{2+}\right]_{\mathrm{i}}$ increase (mean $+\mathrm{SD}$ ) produced by OXA (17-33) $(0.1,1,10$, and $100 \mathrm{nM}) ; p<0.05$ as compared with the amplitude of $\left[\mathrm{Ca}^{2+}\right]_{\mathrm{i}}$ increase produced by each concentration $\left(^{*}\right)$ or by OXA $(17-33)(10 \mathrm{nM})\left(^{* *}\right) ; n=6$ neurons/each concentration tested. 


\subsection{OXA (17-33) Increases $\left[\mathrm{Ca}^{2+}\right]_{i}$ via $I P_{3}$-Dependent Mechanism}

In $\mathrm{Ca}^{2+}$-free saline, OXA (17-33) $(10 \mathrm{nM})$ elicited an increase in $\left[\mathrm{Ca}^{2+}\right]_{i}$ of lower amplitude (Figure 2) than in $\mathrm{Ca}^{2+}$-containing saline (Figure 1). The $\mathrm{Ca}^{2+}$ response to OXA (17-33) $(10 \mathrm{nM})$ in $\mathrm{Ca}^{2+}$-free saline was abolished by pretreatment with $\mathrm{IP}_{3}$ receptors antagonists 2-aminoethoxydiphenyl borate (2-APB, $100 \mu \mathrm{M}, 15 \mathrm{~min}$ ) and xestospongin $\mathrm{C}$ (10 $\mu \mathrm{M}, 15 \mathrm{~min})$ [32], indicating a PLC-dependent mechanism. Disruption of lysosomal $\mathrm{Ca}^{2+}$ stores with bafilomycin A1 $(1 \mu \mathrm{M}, 1 \mathrm{~h}$ preincubation), a V-type ATPase inhibitor that prevents lysosomal acidification [33], did not affect the $\mathrm{Ca}^{2+}$ response to orexin (10 nM) (Figure 2). OXA (17-33) $\left(10 \mathrm{nM}\right.$ )-induced $\mathrm{Ca}^{2+}$ responses (average $\left.\pm \mathrm{SD}\right)$ in $\mathrm{Ca}^{2+}$-free saline in nucleus accumbens neurons in the absence and presence of 2-APB and xestospongin $C$ or bafilomycin A1 are illustrated in Figure 2A, and a comparison of the amplitude of the $\left[\mathrm{Ca}^{2+}\right]_{\mathrm{i}}$ increase in each condition is illustrated in Figure $2 \mathrm{~B}$ ( $n=6$ neurons/condition).
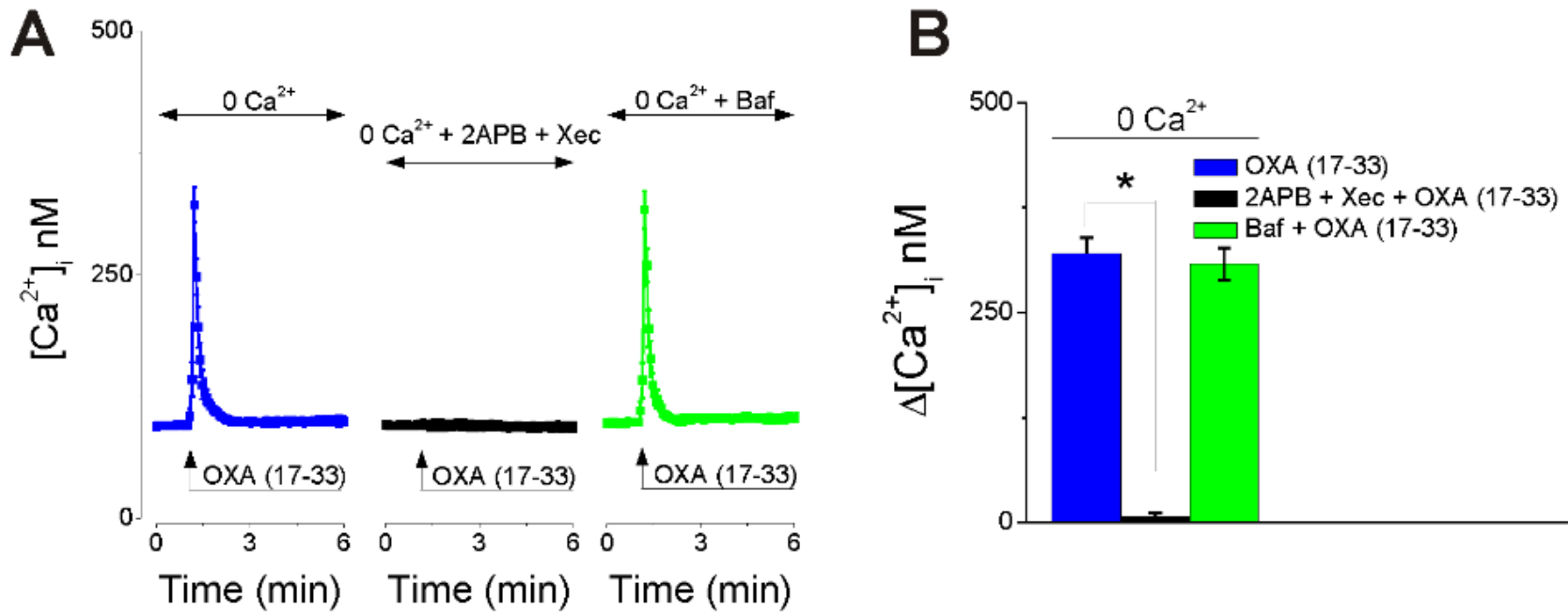

Figure 2. OXA (17-33) increases $\left[\mathrm{Ca}^{2+}\right]_{\mathrm{i}}$ via $\mathrm{IP}_{3}$-dependent mechanism. (A) Illustration of average $\mathrm{Ca}^{2+}$ transients $( \pm \mathrm{SD})$ induced in $\mathrm{Ca}^{2+}$-free saline by OXA (17-33) (10 nM) alone (left) and OXA (17-33) (10 nM) after pretreatment with 2aminoethoxydiphenyl borate (2-APB, $100 \mu \mathrm{M})$ and xestospongin $\mathrm{C}(\mathrm{XeC}, 10 \mu \mathrm{M}, 15 \mathrm{~min}), \mathrm{IP}_{3}$ receptor antagonists (middle), or with bafilomycin A1 (Baf, $1 \mu \mathrm{M}$ ) (right). (B) Comparison of the amplitude of the increase in $\left[\mathrm{Ca}^{2+}\right]_{\mathrm{i}}$ (average $\left.+\mathrm{SD}\right)$ in each condition. Pretreatment with $2-\mathrm{APB}$ and xestospongin $\mathrm{C}$ abolished the $\mathrm{Ca}^{2+}$ response induced by OXA $(17-33) .{ }^{*} p<0.05$; $n=6$ neurons/condition.

\subsection{OXA (17-33) Increases $\left[\mathrm{Ca}^{2+}\right]_{i}$ via Choline-Sigma-1R-Dependent Mechanism}

Pretreatment with VU0155056 (1 $\mu \mathrm{M}, 30 \mathrm{~min})$, a PLD inhibitor [34], reduced the amplitude of OXA (17-33) (10 nM)-induced increase in $\left[\mathrm{Ca}^{2+}\right]_{\mathrm{i}}$ by $33 \%$ (Figure 3). Pretreatment with BD1047 (50 $\mu \mathrm{M}, 30 \mathrm{~min})$ or NE-100 (5 $\mu \mathrm{M}, 30 \mathrm{~min})$ (Sigma-1R antagonists) [35,36] reduced the $\mathrm{Ca}^{2+}$ response to OXA (17-33) $(10 \mathrm{nM})$ by $18.1 \%$ and $20.4 \%$, respectively. Average $\mathrm{Ca}^{2+}$ responses induced by OXA (17-33) alone and in the presence of PLD inhibitor and Sigma-1R antagonists are illustrated in Figure 3A, and a comparison of the amplitude of the $\left[\mathrm{Ca}^{2+}\right]_{\mathrm{i}}$ increase in each condition is illustrated in Figure 3B ( $n=6$ neurons/condition).

\subsection{Cocaine Potentiates OXA (17-33)-Induced Increase in $\left[\mathrm{Ca}^{2+}\right]_{i}$ via Sigma-1R Activation}

Cocaine $(10 \mu \mathrm{M})$, while it did not elicit a $\mathrm{Ca}^{2+}$ response by itself, potentiated the increase in $\left[\mathrm{Ca}^{2+}\right]_{\text {i }}$ produced by OXA (17-33) $(10 \mathrm{nM})$, when added at the same time as OXA (17-33) (Figure 4). Pretreatment with BD1047 (50 $\mu \mathrm{M}, 30 \mathrm{~min}$ ) or NE-100 (5 $\mu \mathrm{M}, 30$ $\mathrm{min})$, Sigma-1R antagonists, reduced the increase in $\left[\mathrm{Ca}^{2+}\right]_{i}$ produced by cocaine + OXA (17-33) $(10 \mathrm{nM}$ ), by $30.7 \%$ and $33.1 \%$, respectively (Figure 4$)$. This indicates that antagonism of Sigma-1R abolished the potentiation produced by cocaine and further reduced the $\mathrm{Ca}^{2+}$ response to OXA (17-33) $(10 \mathrm{nM})$ to the same level as in neurons treated with Sigma-1R 
antagonists before OXA (17-33) alone (Figure 4 vs. Figure 3). A comparison of the amplitude of the $\left[\mathrm{Ca}^{2+}\right]_{\mathrm{i}}$ increase in each condition is illustrated in Figure $4 \mathrm{~B}$ ( $n=6$ neurons/condition).
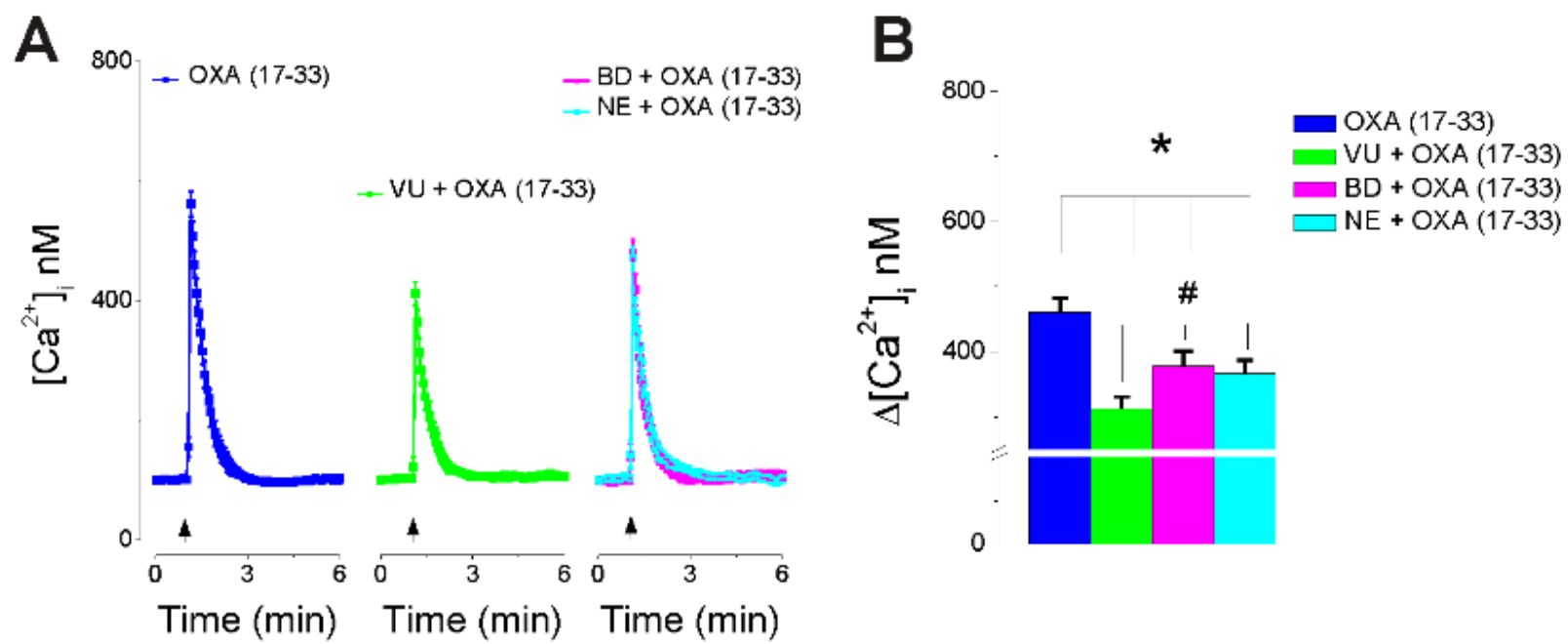

Figure 3. OXA (17-33) A increases $\left[\mathrm{Ca}^{2+}\right]_{\mathrm{i}}$ via choline-Sigma-1R-dependent mechanism. (A) Illustration of average Ca ${ }^{2+}$ transients ( \pm SD) induced by OXA (17-33) (10 nM) alone (left) and in the presence of VU0155056 (1 $\mu$ M), PLD inhibitor (middle), and BD1047 (50 $\mu \mathrm{M})$ or NE-100 $(5 \mu \mathrm{M})$, Sigma-1R antagonists (right). (B) Comparison of the amplitude of the increase in $\left[\mathrm{Ca}^{2+}\right]_{\mathrm{i}}$ (average $+\mathrm{SD}$ ) in each condition. Inhibition of PLD or antagonism of Sig-1R reduces the Ca ${ }^{2+}$ response elicited by OXA (17-33) $(10 \mathrm{nM}) ; p<0.05$ as compared to amplitude of $\left[\mathrm{Ca}^{2+}\right]_{\mathrm{i}}$ increase produced by OXA $(17-33)\left({ }^{*}\right)$ or produced in the presence of the inhibitors $\left(^{\#}\right)(n=6$ neurons/condition).
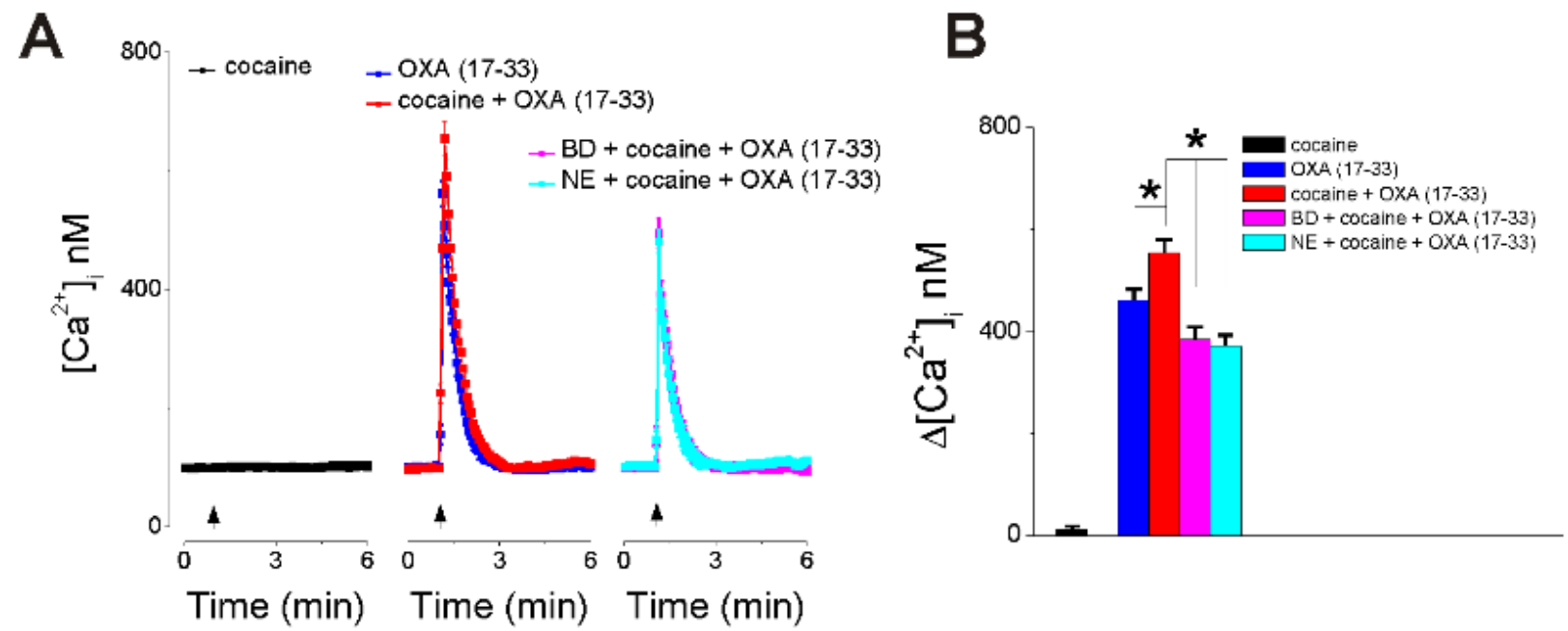

Figure 4. Cocaine potentiates OXA (17-33)-induced increase in $\left[\mathrm{Ca}^{2+}\right]_{\mathrm{i}}$ via Sigma-1R activation. (A) Illustration of average $\mathrm{Ca}^{2+}$ responses $( \pm \mathrm{SD})$ produced by application of cocaine $(10 \mu \mathrm{M})$ alone (left, no response), cocaine $(10 \mu \mathrm{M})$ and $\mathrm{OXA}$ (17-33) (10 nM) (middle), and cocaine and OXA (17-33) in the presence of Sigma-1R antagonists BD1047 (50 $\mu \mathrm{M})$ or NE-100 $(5 \mu \mathrm{M})$ (right). (B) Comparison of the amplitude of the increase in $\left[\mathrm{Ca}^{2+}\right]_{\mathrm{i}}$ (average $\left.+\mathrm{SD}\right)$ in each condition. Cocaine potentiates the $\mathrm{Ca}^{2+}$ response induced by OXA (17-33), while antagonism of Sigma-1R abolished the potentiation produced by cocaine on the $\mathrm{Ca}^{2+}$ response elicited by OXA (17-33) $(10 \mathrm{nM}) .{ }^{*} p<0.05$ ( $n=6$ neurons/condition).

A diagram summarizing the proposed mechanism of potentiation of orexin by cocaine via Sigma-1R activation in nucleus accumbens neurons is illustrated in Figure 5. 


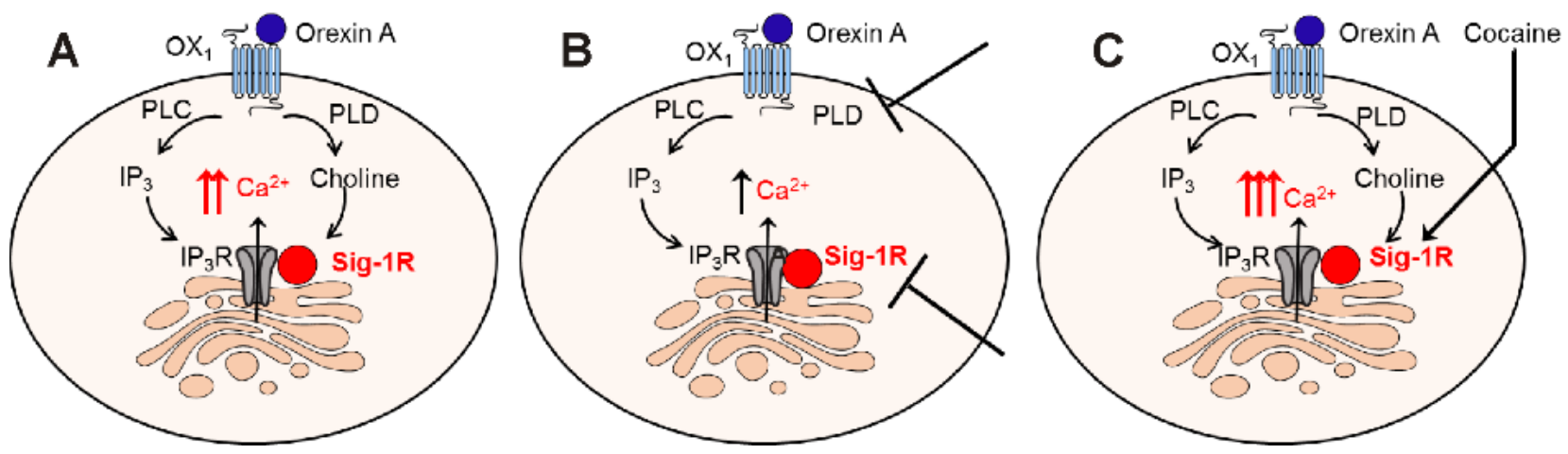

Figure 5. Diagram illustrating the proposed model of potentiation of orexin by cocaine via Sigma-1R in nucleus accumbens neurons. (A) Orexin A acting on $\mathrm{OX}_{1}$ receptor activates PLC and PLD. PLC increases $\mathrm{IP}_{3}$ level and promotes the Ca ${ }^{2+}$ release from endoplasmic reticulum via $\mathrm{IP}_{3}$ receptors $\left(\mathrm{IP}_{3} \mathrm{R}\right)$. PLD produces choline (from hydrolysis of phosphatidylcholine) that acts on Sigma-1R to potentiate $\mathrm{Ca}^{2+}$ increase via $\mathrm{IP}_{3} \mathrm{R}$ (higher increase in $\left[\mathrm{Ca}^{2+}\right]_{\mathrm{i}}$ ). (B) Inhibition of PLD or antagonism of Sigma-1R limits the orexin A-OX 1 receptor signaling to PLC-mediated $\mathrm{IP}_{3}$-dependent increase in $\mathrm{Ca}^{2+}\left(\mathrm{smaller}^{2}\right.$ increase in $\left.\left[\mathrm{Ca}^{2+}\right]_{\mathrm{i}}\right) .(\mathrm{C})$ Cocaine, via Sigma-1R activation, potentiates the PLC- and PLD-mediated increase in $\left[\mathrm{Ca}^{2+}\right]_{\mathrm{i}}$ produced by orexin $\mathrm{A}$ acting on $\mathrm{OX}_{1}$ (highest increase in $\left[\mathrm{Ca}^{2+}\right]_{\mathrm{i}}$ ). The diagram was created using the Motifolio Illustration Toolkit Neuroscience (https:/ / www.motifolio.com accessed on 7 March 2021).

\section{Discussion}

Orexin A, via activation of $\mathrm{OX}_{1}$ receptor, can activate both phospholipase $\mathrm{C}$ (PLC) and phospholipase $\mathrm{D}$ (PLD) in various cell models $[9,10]$ including neurons [37]. PLC activation leads to hydrolysis of phosphoinositides and formation of inositol-1,4,5- trisphosphate (IP3), the $\mathrm{Ca}^{2+}$-releasing second messenger that releases $\mathrm{Ca}^{2+}$ from endoplasmic reticulum (ER) through $\mathrm{IP}_{3}$ receptors [38]. PLD activation promotes the hydrolysis of phosphatidylcholine to choline and phosphatidic acid [11]. Whereas phosphatidic acid was considered the main effector downstream to PLD activation, we recently identified choline as a second messenger that activates Sigma-1R [12].

Sigma-1 receptor is a chaperone protein expressed in the endoplasmic reticulum (ER), mainly at the mitochondria-associated ER membrane domains (MAMs) [13]. Sigma-1Rs interact with many different signaling proteins. At the ER, Sigma-1Rs potentiate the $\mathrm{Ca}^{2+}$ release via $\mathrm{IP}_{3}$ receptors [13]; they also interact with STIM1, the $\mathrm{Ca}^{2+}$ sensor for storeoperated $\mathrm{Ca}^{2+}$ entry [39]. Sigma-1R ligands include antidepressants, antipsychotics, and drugs of abuse [40]. Cocaine, in addition to its canonical target that elevates synaptic dopamine levels, binds to and activates Sigma-1Rs [41,42]. Neurons in the nucleus accumbens, a key area involved in the reward circuit [25], express Sigma-1R [27-29] and OX receptors [14,15]. Behavioral studies supported the cocaine-orexin interaction in nucleus accumbens [3,22], but the underlying mechanisms remained unclear; this prompted us to investigate the mechanisms of cocaine-orexin interaction at this level.

Orexin A has been reported to increase cytosolic $\mathrm{Ca}^{2+}$ concentration, $\left[\mathrm{Ca}^{2+}\right]_{\mathrm{i}}$, in various cells expressing orexin receptors [1], including neurons [43]. We first tested the effect of truncated orexin A peptide, OXA (17-33), a selective OX1 agonist [30], on $\left[\mathrm{Ca}^{2+}\right]_{\mathrm{i}}$ in cultured nucleus accumbens neurons. OXA (17-33) increased $\left[\mathrm{Ca}^{2+}\right]_{\mathrm{i}}$ in a dose-dependent manner; the effect was abolished by SB-334867 $(1 \mu \mathrm{M})$, an $\mathrm{OX}_{1}$ antagonist $[10,31]$ indicating that it was mediated by $\mathrm{OX}_{1}$ receptors.

We next demonstrated that the OXA (17-33)-induced increase in $\left[\mathrm{Ca}^{2+}\right]_{\mathrm{i}}$ was mediated by $\mathrm{IP}_{3}$-dependent $\mathrm{Ca}^{2+}$ release from ER, as previously reported [6]; the effect was abolished by $\mathrm{IP}_{3}$ receptor antagonists, but not affected by disruption of lysosomal $\mathrm{Ca}^{2+}$ stores.

In other series of experiments, pretreatment with PLD inhibitor reduced the $\mathrm{Ca}^{2+}$ response elicited by OXA (17-33), supporting the involvement of PLD activation in addition to $\mathrm{PLC} / \mathrm{IP}_{3}$-dependent mechanisms in nucleus ambiguus neurons. This is in agreement with previous studies reporting PLD-dependent mechanisms downstream to OX1 activation $[9,10,37]$. 
In addition, antagonism of Sigma-1R reduced the $\mathrm{Ca}^{2+}$ response produced by OXA (17-33), indicating for the first time the role of Sigma-1R in the response to $\mathrm{OX}_{1}$ activation in the nucleus accumbens. The reduction in the response to OXA (17-33) produced by PLD inhibition and Sigma-1R antagonism indicates that choline produced by PLD hydrolysis of phosphatidylcholine, acting on Sigma-1R, as recently reported [12], potentiates the $\mathrm{IP}_{3}$-mediated increase in $\left[\mathrm{Ca}^{2+}\right]_{\mathrm{i}}$.

Our results also indicate that cocaine, while it did not elicit a response by itself, potentiated the increase in $\left[\mathrm{Ca}^{2+}\right]_{\mathrm{i}}$ induced by OXA(17-33). This is similar to the potentiation of orexin A-induced increase in $\left[\mathrm{Ca}^{2+}\right]_{\mathrm{i}}$ by cocaine reported in VTA neurons [43]. In VTA neurons, the effect of orexin and the potentiation by cocaine were abolished by suvorexant (MK-4305), a dual orexin receptor $\mathrm{OX}_{1} / \mathrm{OX}_{2}$ antagonist $[43,44]$. Moreover, in nucleus accumbens neurons, the potentiation of orexin response by cocaine was abolished by Sigma-1R antagonists. Cocaine is a Sigma-1R agonist [26], and we previously reported that, in nucleus accumbens neurons, cocaine via Sigma-1R potentiates the $\mathrm{IP}_{3}$-mediated increase in $\left[\mathrm{Ca}^{2+}\right]_{\mathrm{i}}[29]$. Here, we identify an additional signaling mechanism for orexin $\mathrm{A}-\mathrm{OX}_{1}$ via choline-Sigma-1R and a critical role for Sigma- $1 \mathrm{R}$ in the cocaine-orexin A interaction in nucleus accumbens neurons.

\section{Materials and Methods}

\subsection{Chemicals}

OXA (17-33), i.e., truncated orexin A, a selective OX1 agonist [30], SB-334867, a selective nonpeptide $\mathrm{OX}_{1}$ antagonist [31], and BD-1047 and NE-100 (Sigma-1 antagonists) were obtained from Tocris (Bio-Techne Corporation, Minneapolis, MN, USA). VU0155056, a PLD inhibitor [34], was purchased from Avanti Polar Lipids (Alabaster, AL, USA). Cocaine was supplied by the National Institute on Drug Abuse's Drug Supply Program. All other chemicals were from Sigma Aldrich (St. Louis, MO, USA), unless otherwise mentioned.

\subsection{Neuronal Cell Culture}

Nucleus accumbens neurons were dissociated from neonatal Sprague Dawley rats (Ace Animal Inc., Boyertown, PA, USA) of both sexes as previously described [29,45]. Newborn rats were decapitated, and the brains quickly removed surgically and immersed in ice-cold Hanks balanced salt solution (HBSS). The nucleus accumbens was identified, removed, minced, and subjected to enzymatic (papain, $37^{\circ} \mathrm{C}$ ) and mechanical dissociation. Cells were cultured in Neurobasal A medium (Life Technologies, ThermoFisher Scientific, Carlsbad, CA, USA) containing 10\% fetal bovine serum, $1 \%$ GlutaMax, and $1 \%$ penicillinstreptomycin-amphotericin B solution at $37{ }^{\circ} \mathrm{C}$ in a humidified atmosphere with $5 \%$ $\mathrm{CO}_{2}$. The mitotic inhibitor cytosine $\beta$-arabinofuranoside $(1 \mu \mathrm{M})$ was added to the culture to inhibit glial cell proliferation. For calcium imaging, neurons were cultured on round $25 \mathrm{~mm}$ diameter glass coverslips coated with poly-L-lysine, in six-well plates.

\subsection{Measurement of Cytosolic $\mathrm{Ca}^{2+}$ Concentration}

Cytosolic $\mathrm{Ca}^{2+}$ concentration, $\left[\mathrm{Ca}^{2+}\right]_{i}$, was measured by calcium imaging methods in nucleus accumbens neurons loaded with Fura-2AM, as previously described [29,45]. Cells were incubated with $5 \mu \mathrm{M}$ Fura-2AM (Invitrogen) in HBSS at room temperature for $45 \mathrm{~min}$, in the dark, and then incubated for another $45 \mathrm{~min}$ in HBSS to allow for complete de-esterification of the dye. Coverslips ( $25 \mathrm{~mm}$ diameter) were subsequently mounted in an open bath chamber (Warner Instruments, Hamden, CT, USA) on the stage of an inverted microscope Nikon Eclipse TiE (Nikon Inc., Melville, NY, USA), equipped with a Perfect Focus System and a Photometrics CoolSnap HQ2 CCD camera (Photometrics, Tucson, AZ, USA). During the experiments, the Perfect Focus System was activated. Fura-2AM fluorescence (emission $=510 \mathrm{~nm}$ ), following alternate excitation at 340 and $380 \mathrm{~nm}$, was acquired at a frequency of $0.25 \mathrm{~Hz}$. Images were acquired and analyzed using NIS-Elements AR software (Nikon Inc.). After appropriate calibration with ionomycin and $\mathrm{CaCl}_{2}$ and 
with $\mathrm{Ca}^{2+}$ free and EGTA, respectively, the ratio of the fluorescence signals $(340 / 380 \mathrm{~nm})$ was converted to $\mathrm{Ca}^{2+}$ concentrations [46].

\subsection{Data Analysis}

Data were expressed as the mean \pm standard deviation (SD). Datasets were compared for statistically significant differences using one-way ANOVA followed by post hoc Bonferroni test. A $p$-value $<0.05$ was considered statistically significant.

Author Contributions: Conceptualization, E.B.; methodology, J.L.B., P.Z., G.C.B., and E.B.; validation, J.L.B., G.C.B., and E.B.; formal analysis, J.L.B., G.C.B., and E.B.; investigation, J.L.B., P.Z., G.C.B., and E.B.; writing - original draft preparation, G.C.B. and E.B.; writing—review and editing, J.L.B., P.Z., G.C.B., and E.B.; visualization, J.L.B., P.Z., G.C.B., and E.B.; supervision, E.B. All authors have read and agreed to the published version of the manuscript.

Funding: This research was funded by the National Institutes of Health grant number P30DA013429 and research funds from the Jefferson College of Pharmacy.

Institutional Review Board Statement: Animal protocols were approved by the Institutional Animal Care and Use Committee (protocol 01460 approved 20 January 2019).

Informed Consent Statement: Not applicable.

Data Availability Statement: The data generated and analyzed during this study are available in the manuscript.

Conflicts of Interest: The authors declare no conflict of interest.

\section{References}

1. Sakurai, T.; Amemiya, A.; Ishii, M.; Matsuzaki, I.; Chemelli, R.M.; Tanaka, H.; Williams, S.C.; Richardson, J.A.; Kozlowski, G.P.; Wilson, S.; et al. Orexins and orexin receptors: A family of hypothalamic neuropeptides and G protein-coupled receptors that regulate feeding behavior. Cell 1998, 92, 573-585. [CrossRef]

2. de Lecea, L.; Kilduff, T.S.; Peyron, C.; Gao, X.; Foye, P.E.; Danielson, P.E.; Fukuhara, C.; Battenberg, E.L.; Gautvik, V.T.; Bartlett, F.S.; et al. The hypocretins: Hypothalamus-specific peptides with neuroexcitatory activity. Proc. Natl. Acad. Sci. USA 1998, 95, 322-327. [CrossRef] [PubMed]

3. Mahler, S.V.; Smith, R.J.; Moorman, D.E.; Sartor, G.C.; Aston-Jones, G. Multiple roles for orexin/hypocretin in addiction. Prog. Brain Res. 2012, 198, 79-121.

4. Haghparast, A.; Fatahi, Z.; Arezoomandan, R.; Karimi, S.; Taslimi, Z.; Zarrabian, S. Functional roles of orexin/hypocretin receptors in reward circuit. Prog. Brain Res. 2017, 235, 139-154.

5. Foord, S.M.; Bonner, T.I.; Neubig, R.R.; Rosser, E.M.; Pin, J.-P.; Davenport, A.P.; Spedding, M.; Harmar, A.J. International Union of Pharmacology. XLVI. G protein-coupled receptor list. Pharmacol. Rev. 2005, 57, 279-288. [CrossRef] [PubMed]

6. Kukkonen, J.P. G-protein-dependency of orexin/hypocretin receptor signalling in recombinant Chinese hamster ovary cells. Biochem. Biophys. Res. Commun. 2016, 476, 379-385. [CrossRef]

7. Hopf, F.W. Recent perspectives on orexin/hypocretin promotion of addiction-related behaviors. Neuropharmacology 2020, 168, 108013. [CrossRef] [PubMed]

8. Kukkonen, J.P. Lipid signaling cascades of orexin/hypocretin receptors. Biochimie 2014, 96, 158-165. [CrossRef]

9. Johansson, L.; Ekholm, M.E.; Kukkonen, J.P. Multiple phospholipase activation by OX(1) orexin/hypocretin receptors. Cell. Mol. Life Sci. 2008, 65, 1948-1956. [CrossRef]

10. Jantti, M.H.; Putula, J.; Somerharju, P.; Frohman, M.A.; Kukkonen, J.P. OX1 orexin/hypocretin receptor activation of phospholipase D. Br. J. Pharmacol. 2012, 165, 1109-1123. [CrossRef] [PubMed]

11. Exton, J.H. Phospholipase D. Ann. N. Y. Acad. Sci. 2000, 905, 61-68. [CrossRef]

12. Brailoiu, E.; Chakraborty, S.; Brailoiu, G.C.; Zhao, P.; Barr, J.L.; Ilies, M.A.; Unterwald, E.M.; Abood, M.E.; Taylor, C.W. Choline is an intracellular messenger linking extracellular stimuli to IP3-evoked $\mathrm{Ca}(2+)$ signals through Sigma-1 receptors. Cell Rep. 2019, 26, 330-337. [CrossRef] [PubMed]

13. Hayashi, T.; Su, T.P. Sigma-1 receptor chaperones at the ER-mitochondrion interface regulate Ca(2+) signaling and cell survival. Cell 2007, 131, 596-610. [CrossRef] [PubMed]

14. D'Almeida, V.; Hipolide, D.C.; Raymond, R.; Barlow, K.B.L.; Parkes, J.H.; Pedrazzoli, M.; Tufik, S.; Nobrega, J.N. Opposite effects of sleep rebound on orexin OX1 and OX2 receptor expression in rat brain. Brain Res. Mol. Brain Res. 2005, 136, 148-157. [CrossRef]

15. Lei, K.; Kwok, C.; Darevsky, D.; Wegner, S.A.; Yu, J.; Nakayama, L.; Pedrozo, V.; Anderson, L.; Ghotra, S.; Fouad, M.; et al. Nucleus accumbens shell Orexin-1 receptors are critical mediators of binge intake in excessive-drinking individuals. Front. Neurosci. 2019, 13, 88. [CrossRef] 
16. Perrey, D.A.; Zhang, Y. Therapeutics development for addiction: Orexin-1 receptor antagonists. Brain Res. 2020, $1731,145922$. [CrossRef]

17. Han, Y.; Yuan, K.; Zheng, Y.; Lu, L. Orexin receptor antagonists as emerging treatments for psychiatric disorders. Neurosci. Bull. 2020, 36, 432-448. [CrossRef]

18. Khoo, S.Y.; Brown, R.M. Orexin/hypocretin based pharmacotherapies for the treatment of addiction: DORA or SORA? CNS Drugs 2014, 28, 713-730. [CrossRef]

19. Bentzley, B.S.; Aston-Jones, G. Orexin-1 receptor signaling increases motivation for cocaine-associated cues. Eur. J. Neurosci. 2015, 41, 1149-1156. [CrossRef]

20. Zhou, L.; Ghee, S.M.; Chan, C.; Lin, L.; Cameron, M.D.; Kenny, P.J.; See, R.E. Orexin-1 receptor mediation of cocaine seeking in male and female rats. J. Pharmacol. Exp. Ther. 2012, 340, 801-809. [CrossRef]

21. Prince, C.D.; Rau, A.R.; Yorgason, J.T.; Espana, R.A. Hypocretin/Orexin regulation of dopamine signaling and cocaine selfadministration is mediated predominantly by hypocretin receptor 1. ACS Chem. Neurosci. 2015, 6, 138-146. [CrossRef] [PubMed]

22. Yang, M.; Ma, H.; Jia, M.; Li, Y.; Miao, D.; Cui, C.; Wu, L. The role of the nucleus accumbens OXR1 in cocaine-induced locomotor sensitization. Behav. Brain Res. 2020, 379, 112365. [CrossRef] [PubMed]

23. Martin-Fardon, R.; Weiss, F. Blockade of hypocretin receptor-1 preferentially prevents cocaine seeking: Comparison with natural reward seeking. Neuroreport 2014, 25, 485-488. [CrossRef] [PubMed]

24. Giros, B.; Jaber, M.; Jones, S.R.; Wightman, R.M.; Garon, M.G. Hyperlocomotion and indifference to cocaine and amphetamine in mice lacking the dopamine transporter. Nature 1996, 379, 606-612. [CrossRef]

25. Koob, G.F.; Volkow, N.D. Neurocircuitry of addiction. Neuropsychopharmacology 2010, 35, 217-238. [CrossRef]

26. Sharkey, J.; Glen, K.A.; Wolfe, S.; Kuhar, M.J. Cocaine binding at sigma receptors. Eur. J. Pharmacol. 1988, 149, 171-174. [CrossRef]

27. Gundlach, A.L.; Largent, B.L.; Snyder, S.H. Autoradiographic localization of sigma receptor binding sites in guinea pig and rat central nervous system with (+)3H-3-(3-hydroxyphenyl)-N-(1-propyl)piperidine. J. Neurosci. 1986, 6, 1757-1770. [CrossRef]

28. Alonso, G.; Phan, V.; Guillemain, I.; Saunier, M.; Legrand, A.; Anoal, M.; Maurice, T. Immunocytochemical localization of the sigma(1) receptor in the adult rat central nervous system. Neuroscience 2000, 97, 155-170. [CrossRef]

29. Barr, J.L.; Deliu, E.; Brailoiu, C.G.; Zhao, P.; Yan, G.; Abood, M.E.; Unterwald, E.M.; Brailoiu, E. Mechanisms of activation of nucleus accumbens neurons by cocaine via sigma-1 receptor-inositol 1,4,5-trisphosphate-transient receptor potential canonical channel pathways. Cell Calcium 2015, 58, 196-207. [CrossRef]

30. Feng, X.M.; Mi, W.L.; Xia, F.; Mao-Ying, W.L.; Jiang, J.W.; Xiao, S.; Wang, Z.F.; Wang, Y.Q.; Wu, G.C. Involvement of spinal orexin $\mathrm{A}$ in the electroacupuncture analgesia in a rat model of post-laparotomy pain. BMC Complement. Altern. Med. 2012, 12, 225. [CrossRef]

31. Smart, D.; Sabido-David, C.; Brough, S.J.; Jewitt, F.; Johns, A.; Porter, R.A.; Jerman, J.C. SB-334867-A: The first selective orexin-1 receptor antagonist. Br. J. Pharmacol. 2001, 132, 1179-1182. [CrossRef]

32. Maruyama, T.; Kanaji, T.; Nakade, S.; Kanno, T.; Mikoshiba, K. 2APB, 2-aminoethoxydiphenyl borate, a membrane-penetrable modulator of Ins(1,4,5)P3-induced $\mathrm{Ca}^{2+}$ release. J. Biochem. 1997, 122, 498-505. [CrossRef] [PubMed]

33. Bowman, E.J.; Siebers, A.; Altendorf, K. Bafilomycins: A class of inhibitors of membrane ATPases from microorganisms, animal cells, and plant cells. Proc. Natl. Acad. Sci. USA 1988, 85, 7972-7976. [CrossRef]

34. Scott, S.A.; Selvy, P.E.; Buck, J.R.; Cho, H.P.; Criswell, T.L.; Thomas, A.L.; Armstrong, M.D.; Arteaga, C.L.; Lindsley, C.W.; Brown, H.A. Design of isoform-selective phospholipase D inhibitors that modulate cancer cell invasiveness. Nat. Chem. Biol. 2009, 5, 108-117. [CrossRef]

35. Matsumoto, R.R.; Bowen, W.D.; Tom, M.A.; Vo, V.N.; Truong, D.D.; de Costa, B.R. Characterization of two novel sigma receptor ligands: Antidystonic effects in rats suggest sigma receptor antagonism. Eur. J. Pharmacol. 1995, 280, 301-310. [CrossRef]

36. Chaki, S.; Okuyama, S.; Ogawa, S.; Tanaka, M.; Muramatsu, M.; Nakazato, A.; Tomisawa, K. Solubilization and characterization of binding sites for $\left[{ }^{3} \mathrm{H}\right] \mathrm{NE}-100$, a novel and potent sigma 1 ligand, from guinea pig brain. Life Sci. 1996, 59, 1331-1340. [CrossRef]

37. Bjornstrom, K.; Turina, D.; Strid, T.; Sundqvist, T.; Eintrei, C. Orexin A inhibits propofol-induced neurite retraction by a phospholipase D/protein kinase Cepsilon-dependent mechanism in neurons. PLoS ONE 2014, 9, e97129. [CrossRef]

38. Berridge, M.J. The Inositol Trisphosphate/Calcium signaling pathway in health and disease. Physiol. Rev. 2016, 96, 1261-1296. [CrossRef]

39. Srivats, S.; Balasuriya, D.; Pasche, M.; Vistal, G.; Edwardson, J.M.; Taylor, C.W.; Murell-Lagnado, R.D. Sigma1 receptors inhibit store-operated Ca2+ entry by attenuating coupling of STIM1 to Orai1. J. Cell Biol. 2016, 213, 65-79. [CrossRef]

40. Maurice, T.; Su, T.P. The pharmacology of sigma-1 receptors. Pharmacol. Ther. 2009, 124, 195-206. [CrossRef]

41. Katz, J.L.; Hong, W.C.; Hiranita, T.; Su, T.P. A role for sigma receptors in stimulant self-administration and addiction. Pharmaceuticals 2011, 4, 880-914. [CrossRef]

42. Hayashi, T.; Tsai, S.Y.; Mori, T.; Fujimoto, M.; Su, T.P. Targeting ligand-operated chaperone sigma-1 receptors in the treatment of neuropsychiatric disorders. Expert Opin. Ther. Targets 2011, 15, 557-577. [CrossRef] [PubMed]

43. Gentile, T.A.; Simmons, S.J.; Watson, M.N.; Connelly, K.L.; Brailoiu, E.; Zhang, Y.; Muschamp, J.W. Effects of suvorexant, a dual Orexin/Hypocretin receptor antagonist, on impulsive behavior associated with cocaine. Neuropsychopharmacology 2018, 43, 1001-1009. [CrossRef] 
44. Cox, C.D.; Breslin, M.J.; Whitman, D.B.; Schreier, J.D.; McGaughey, G.B.; Bogusky, M.J.; Roecker, A.J.; Mercer, S.P.; Bednar, R.A.; Lemaire, W.; et al. Discovery of the dual orexin receptor antagonist [(7R)-4-(5-chloro-1,3-benzoxazol-2-yl)-7-methyl-1,4-diazepan1-yl][5-methyl-2-(2H-1,2,3-triazol-2-yl)phenyl]methanone (MK-4305) for the treatment of insomnia. J. Med. Chem. 2010, 53, 5320-5332. [CrossRef]

45. Brailoiu, G.C.; Deliu, E.; Barr, J.L.; Console-Bram, L.M.; Ciuciu, A.M.; Abood, M.E.; Unterwald, E.M.; Brailoiu, E. HIV Tat excites D1 receptor-like expressing neurons from rat nucleus accumbens. Drug Alcohol Depend. 2017, 178, 7-14. [CrossRef] [PubMed]

46. Grynkiewicz, G.; Poenie, M.; Tsien, R.Y. A new generation of $\mathrm{Ca}^{2+}$ indicators with greatly improved fluorescence properties. J. Biol. Chem. 1985, 260, 3440-3450. [CrossRef] 